Canadian Journal of Soil Science Revue canadienne de la science du sol

\title{
Soil organic carbon changes as influenced by carbon inputs and previous cropping system
}

\begin{tabular}{|c|c|}
\hline Journal: & Canadian Journal of Soil Science \\
\hline Manuscript ID & CJSS-2017-0120.R2 \\
\hline Manuscript Type: & Short Communication \\
\hline Date Submitted by the Author: & 14-Mar-2018 \\
\hline Complete List of Authors: & $\begin{array}{l}\text { Smith, Elwin; Agriculture and Agri-Food Canada, Science and Technology } \\
\text { Branch } \\
\text { Janzen, Henry; Agriculture and Agri-Food Canada, Science and Technolgy } \\
\text { Branch } \\
\text { Ellert, Benjamin; Agriculture and Agri-Food Canada }\end{array}$ \\
\hline Keywords: & Cropping system, Nitrogen, soil organic carbon, carbon input \\
\hline $\begin{array}{r}\text { Is the invited manuscript for } \\
\text { consideration in a Special } \\
\text { Issue?: }\end{array}$ & Not applicable (regular submission) \\
\hline
\end{tabular}

\section{SCHOLARONE}

Manuscripts 
Soil organic carbon changes as influenced by carbon inputs and previous cropping system Elwin G. Smith, H. Henry Janzen, and Benjamin H. Ellert

Agriculture and Agri-Food Canada, Lethbridge Research and Development Centre, Lethbridge T1J 4B1, Alberta, Canada. Contribution Number 38717077

\begin{abstract}
We planted continuous wheat, with and without nitrogen fertilizer, onto a preceding long-term (44 yr) experiment with contrasting cropping systems, and measured soil organic carbon (SOC) after six years. Changes in SOC were driven mostly by cumulative plant C inputs, as influenced by yield response to added nitrogen.
\end{abstract}

Key words: soil organic carbon, cropping system, nitrogen, carbon mass

Crop production systems are a main factor determining the concentration of soil organic carbon (SOC) (Janzen et al. 1998). Systems with higher yields and reduced fallow frequency favour greater SOC. The stability of management-induced SOC differences when these systems are changed, however, has rarely been measured.

The objective of this study was to determine the effects of short-term (6 yr) cropping system changes in SOC when the systems were initially in a steady state. A 44 year experiment at Lethbridge, $\mathrm{AB}$ with various cropping systems induced large differences in SOC concentration (Smith et al. 2015). We temporarily changed the cropping system to continuous spring wheat (Triticum aestivum L.) to measure the persistence of SOC once the cropping systems were altered. 
The long-term cropping system study was initiated in 1951 at the Agriculture and AgriFood Canada Research and Development Centre at Lethbridge, AB (lat. 49.705N, long. 112.775W). The field has level topography, and is an Orthic Dark Brown Chernozem with clay loam texture and calcareous subsoil. Prior to the initiation of this study, there were 13 cropping systems, some initiated in 1951, and the remainder in 1985 (Table 1) (Smith et al. 2012). Plots $(3.2 \mathrm{~m} \times 36.6 \mathrm{~m})$ were arranged in a randomized complete block design with four replicates.

For the period from 1995 through 2000, the cropping system treatments and associated amendments were suspended, no-till was used, and the entire area was sown to hard red spring wheat (cultivar 'Katepwa'; $84 \mathrm{~kg} \mathrm{ha}^{-1}$ ) as a bioassay of soil productivity (Smith et al. 2015). Each of the four replicate blocks was divided into two strips, and each year $\mathrm{N}$ fertilizer was applied to the same randomly assigned strip, such that all plot halves $(3.2 \times 18.3 \mathrm{~m})$ on one side of the block received fertilizer $\mathrm{N}$ while the halves on the other side did not receive $\mathrm{N}$.. The $\mathrm{N}$ rate $(\mathrm{kg} \mathrm{N}$ $\mathrm{ha}^{-1}$ ) for an expected yield was 50 for 1995, 56 for 1996, 1998, 1999 and 2000, and 59 for 1997. Monocalcium phosphate fertilizer (0-45-0) was applied with the seed at rates from 6 to $9 \mathrm{~kg} \mathrm{P}$ $\mathrm{ha}^{-1}$. Potassium and sulphur levels in these soils were adequate. Pre-seed weed control was by a spring burn-off with glyphosate. In-crop weeds were controlled with selective herbicides at label rates. Harvest was by a small-plot combine, after the original blocks were subdivided according to $\mathrm{N}$ fertilizer rate, so the total number of plots during 1995 through 2000 was twice the number before this period. The center portion of each plot was threshed and wheat grain samples were dried for $7 \mathrm{~d}$ at $60^{\circ} \mathrm{C}$ to obtain moisture contents, allowing grain yields to be expressed on a dry weight basis.

Soil samples (0- to $7.5-\mathrm{cm}, 7.5$ - to $15-\mathrm{cm}$, and 15 - to $30-\mathrm{cm}$ depths) were obtained from all plots, at the beginning (spring, 1995) and end (fall, 2000) of the study. In 1995, the sample 
was a composite of four soil cores from across the plot. In 2000, a composite sample was similarly obtained, but separately on both the control and N-fertilized halves of each plot. Soils were dried, weighed to obtain core density, and coarsely ground ( $<2 \mathrm{~mm})$ using a perforated drum sieve [Rukuhia mill (Waters and Sweetman 1955)]. Subsamples were finely ground to pass through a $150-\mu \mathrm{m}$ screen, and then analyzed for total $\mathrm{C}$ and $\mathrm{N}$ by dry combustion with an automated CN analyzer (CE Instruments, Milan, Italy). The fine subsamples were analyzed again to determine organic $\mathrm{C}$ and total $\mathrm{N}$ using a small-scale acidification technique to remove soil carbonates (Ellert and Rock 2007), and the same CN analyzer.

Carbon inputs over the $6 \mathrm{yr}$ were estimated from wheat yield. The grain $\mathrm{C}$ fraction (removed from the plots) was assumed to be 0.322 of the total $\mathrm{C}$ fixed by the crop (Bolinder et al. 2007). The balance of the $C$ fixed by the crop, 0.678 , was returned to the soil as straw, chaff, leaves, roots, and root exudates. Plant $\mathrm{C}$ inputs were estimated for each plot half by year, and summed over the 6 years.

The change to SOC for the 0 - to $7.5-\mathrm{cm}$ depth was influenced by $\mathrm{N}$ fertilizer treatment $(p=0.024)$ and, to a lesser extent, by the prior cropping system $(p=0.083)$. For the 7.5 - to $15-\mathrm{cm}$ and 15 - to $30-\mathrm{cm}$ depths, neither $\mathrm{N}$ fertilizer $(p=0.169$ and $p=0.494$, respectively) nor cropping system ( $p=0.573$ and $p=0.547$, respectively) significantly influenced the change in SOC. Given the significance of SOC change by depth, we consider only the 0 - to 7.5 -cm depth. This soil layer, as observed also earlier in this study (Bremer et al. 1994), is generally most responsive to management. The SOC for 1995 , the change to SOC for the $0-$ to $7.5-\mathrm{cm}$ depth, and the estimated $\mathrm{C}$ returned to the soil from biomass and root production are reported in Table 1.

As reported by Smith et al. (2015), the 1995 SOC concentration for the 0- to $7.5-\mathrm{cm}$ depth was significantly influenced by the prior cropping system, with the highest SOC content 
for grass and manured systems, and lowest concentrations for fallow-containing systems without fertilizer, legume or manure N sources. During the bioassay years (1995 to 2000), SOC concentrations in the 0 - to $7.5-\mathrm{cm}$ soil layer declined in all sub-plots receiving no $\mathrm{N}$ fertilizer (Table 1). The loss was directly proportional to initial SOC content: those plots with highest initial SOC lost the most (Figure 1), as observed also by Yanni et al. (2016). A similar relationship was observed in N-fertilized sub-plots, but the amount of loss was less, and soils with initially low SOC concentration showed gains (Figure 1). The slopes of the two lines in the figure were identical (interaction $p>0.98$ ) indicating the initial SOC influenced the change and that $\mathrm{N}$ fertilizer was additive and the same for all initial SOC levels. This beneficial effect of added $\mathrm{N}$ for preserving SOC can be related largely to enhanced return of crop residue C (Table 1).

The change in SOC concentration for sub-plot i $\left(\triangle S O C_{i}\right)$ over the 6 years for the 0 - to 7.5-cm depth was estimated by multiple regression to be:

$\Delta S O C_{i}=4.540-0.41017 * S O C_{1995 i}+0.1788 * C_{i}\left(\mathrm{R}^{2}=0.40\right)$ where $S_{0 C} C_{1995 i}$ was the SOC concentration in $1995\left(\mathrm{~g} \mathrm{~kg}^{-1}\right)$ for sub-plot i, and $C_{i}\left(\mathrm{Mg} \mathrm{ha}^{-1}\right)$ was the estimated C input from wheat production from 1995 through 2000 for sub- plot i. The parameter estimates were all well-defined and highly significant $(\mathrm{p}<0.0001)$. Plots with higher SOC in 1995 had a greater decline in SOC, but the decline was moderated by higher C input associated with higher wheat yield (Table 1). The higher the initial SOC, the greater the $\mathrm{C}$ input required to maintain SOC. This observation, likely reflecting largely changes to the 'young' SOC pool, is consistent with C models (Andrén and Kätterer 2001).

Using the above equation for the fallow-wheat (FW) cropping system and C inputs of 7.02 (without $\mathrm{N}$ ) and $12.79 \mathrm{Mg} \mathrm{ha}^{-1}$ (with N) (Table 1), the SOC concentration would not change 
$\left(\Delta \mathrm{SOC}_{\mathrm{i}}=0\right)$ over the $6 \mathrm{yr}$ if the initial SOC was $14.1 \mathrm{~g} \mathrm{SOC} \mathrm{kg}^{-1}$ without $\mathrm{N}$ and $16.6 \mathrm{~g} \mathrm{SOC} \mathrm{kg}^{-1}$ with N. Initial SOC concentration for the FW system was $15.3 \mathrm{~g} \mathrm{~kg}^{-1}$, and the observed SOC concentration declined without $\mathrm{N}$, but increased with $\mathrm{N}$. Total $\mathrm{C}$ input over the 6 yr required for SOC to remain at $15.3 \mathrm{~g} \mathrm{~kg}^{-1}$ was $9.7 \mathrm{Mg} \mathrm{ha}^{-1}\left(1.62 \mathrm{Mg} \mathrm{ha}^{-1} \mathrm{yr}^{-1}\right)$, which was greater than the C input without $\mathrm{N}$ but less than the $\mathrm{C}$ input with $\mathrm{N}$ (Table 1). Poffenbarger et al. (2017) estimated that for continuous maize (Zea mays L.), annual C input of $3.2 \mathrm{Mg} \mathrm{ha}^{-1}$ was required to maintain levels of SOC. For the native mixed-grass (G) cropping system, the concentration of SOC would remain constant over the $6 \mathrm{yr}$ when initial SOC was 14.9 and $16.2 \mathrm{~g} \mathrm{SOC} \mathrm{kg}^{-1}$, respectively, for without and with $\mathrm{N}$ fertilizer. The initial SOC in 1995 was $19.9 \mathrm{~g} \mathrm{~kg}^{-1}$ (Table 1). To maintain SOC over the 6 yr for this cropping system, total C input would need to be approximately 20.4 $\mathrm{Mg} \mathrm{ha}^{-1}\left(3.4 \mathrm{Mg} \mathrm{ha}^{-1} \mathrm{yr}^{-1}\right)$. Thus the higher SOC stored with the grass system cannot be maintained under cereal production, even with fertilization and minimal tillage, as practiced during the bioassay years.

A short-term radical change to a cropping system will alter soil properties. The SOC concentration in the upper soil layer $(0-$ to $7.5-\mathrm{cm})$ adjusted to system changes within $6 \mathrm{yr}$. The SOC adjustment was larger when the past cropping system had higher SOC, and when N fertilizer, manure, or perennial forage were eliminated from systems. In contrast to notions that fertilizer N promotes SOC decline (Mulvaney et al. 2009), these results seem consistent with the maintenance of SOC favoured by greater plant $\mathrm{C}$ inputs associated with $\mathrm{N}$ fertilization (Ladha et al. 2011). Maintaining SOC required C inputs to be returned to the soil in proportion to the concentration of SOC to be maintained.

Acknowledgements 
We thank Linda Kremenik, Leslie Bihari and Yvonne Bruinsma for soil sampling and laboratory analyses, maintaining the field study, and recording field observations and measurements, and the field crew for seeding, spraying and assistance with harvest and implementing treatments.

\section{References}

Andrén, O., and Kätterer, T. 2001. Basic Principles for Soil Carbon Sequestration and Calculating Dynamic Country-level Balances Including Future Scenarios. Pages 495-511 in R. Lal, J.M. Kimble, R.F. Follett, and B.A. Stewart, eds. Assessment Methods for Soil Carbon. Lewis Publishers, CRC Press, Boca Raton, FL.

Bolinder, M.A., Janzen, H.H., Gregorich, E.G., Angers, D.A., and VandenBygaart, A.J. 2007. An approach for estimating net primary productivity and annual carbon inputs to soil for common agricultural crops in Canada. Agric. Ecosys. Environ. 118: 29-42. doi:10.1016/j.agee.2006.05.013

Ellert, B.H., and Rock, L. 2007. Stable isotopes in soil and environmental research. Pages 693711 in M.R. Cater and E.G. Gregorich, eds. Soil Sampling and Methods of Analysis, 2nd ed. CRC Press, Boca Raton, FL.

Janzen, H.H., Campbell, C.A., Izaurralde, R.C., Ellert, B.H., Juma, N., McGill, W.B., and Zentner, R.P. 1998. Management effects on soil C storage on the Canadian prairies. Soil Till. Res. 47: 181-195. doi:10.1016/S0167-1987(98)00105-6

Ladha, J.K, Reddy, C.K, Padre, A.T, and van Kessel, C. 2011. Role of nitrogen fertilization in sustaining organic matter in cultivated soils. J. Environ. Qual. 40:1756-1766. doi:10.2134/jeq2011.0064 
McConkey, B.G., Liang,B.C., Campbell,C.A., Curtin,D., Moulin, A., Brandt, S.A., and Lafond, G.P. 2003. Crop rotation and tillage impact on carbon sequestration in Canadian prairie soils. Soil Till. Res. 74: 81-90. doi:10.1016/S0167-1987(03)00121-1

Mulvaney, R.L., Khan, S.A., and Ellsworth, T.R. 2009. Synthetic nitrogen fertilizers deplete soil nitrogen: A global dilemma for sustainable cereal production. J. Environ. Qual. 38:2295-2314. doi:10.2134/jeq2008.0527

Poffenbarger, H.J., Barker, D.W., Helmers, M.J., Miguez, F.E., Olk, D.C., Sawyer, J.E., Six, J., and Castellano, M.J. 2071. Maximum soil organic carbon storage in Midwest U.S. cropping systems when crops are optimally nitrogen-fertilized. PLoS ONE. 12(3): p.e0172293. doi.org/10.1371/journal.pone.0172293

Shrestha, B., McConkey, B., Smith, W., Desjardins, R., Campbell, C., Grant, B., and Miller, P. 2013. Effects of crop rotation, crop type and tillage on soil organic carbon in a semiarid climate. Can. J. Soil Sci. 93: 137-146. doi:10.4141/cjss2012-078

Smith, E.G., Janzen, H.H., Ellert, B.H., and Nakonechny, D.J. 2012. Rotation 120 - Lethbridge Alberta. Prairie Soils Crops 5: 155-164.

Smith, E.G., Janzen, H.H., and Larney, F.J. 2015. Long-term cropping system impact on quality and productivity of a Dark Brown Chernozem in southern Alberta. Can. J. Soil Sci. 95: 177-186. doi:10.4141/cjss-2014-104

Waters, D.F, and Sweetman, I.C. 1955. The Rukuhia soil grinder. Soil Sci. 79: 411-413. Yanni, S.F., Janzen, H.H., Gregorich, E.G., Ellert, B.H., Larney, F.J., Olson, B.M., and Zvomuya, F. 2016. Organic carbon convergence in diverse soils toward steady state: A 21year field bioassay. SSSAJ: 80:1653-1662. doi:10.2136/sssaj2016.07.0214 
Table 1. Soil organic carbon and change to soil organic carbon for the $0-$ to $7.5-\mathrm{cm}$ soil depth, and plant carbon inputs by cropping system and $\mathrm{N}$ fertilizer.

\begin{tabular}{|c|c|c|c|c|c|}
\hline $\begin{array}{l}\text { Prior cropping } \\
\text { system }\end{array}$ & $\begin{array}{l}\text { SOC in } \\
1995\end{array}$ & \multicolumn{2}{|c|}{ SOC change. 1995 to 2000} & \multicolumn{2}{|c|}{$\begin{array}{l}\text { Plant carbon input } \\
\text { (6-yr total) }\end{array}$} \\
\hline & $\mathrm{g} \mathrm{kg}^{-1}$ & $\begin{array}{l}\text { Without } \mathrm{N}, \\
\mathrm{g} \mathrm{kg}^{-1}\end{array}$ & $\begin{array}{l}\text { With N, } \\
\mathrm{g} \mathrm{kg}^{-1}\end{array}$ & $\begin{array}{l}\text { Without N, } \\
\text { Mg ha }^{-1}\end{array}$ & $\begin{array}{l}\text { With N, } \\
\text { Mg ha }^{-1}\end{array}$ \\
\hline W & $18.52 b c$ & $-1.53 a b c$ & $-0.41 a b$ & $8.83 e$ & $13.77 b c$ \\
\hline FW & $15.31 \mathrm{~g}$ & $-0.39 a$ & $0.57 a$ & $7.02 g$ & $12.79 c d$ \\
\hline FWW & $16.44 f$ & $-0.74 a b$ & $-0.07 a b$ & $7.85 f g$ & $13.04 c$ \\
\hline $\mathrm{W}(+\mathrm{N})$ & $17.97 c d e$ & $-0.64 a b c$ & $0.16 a b$ & $10.57 b c$ & $14.65 a b$ \\
\hline $\mathrm{FW}(+\mathrm{N})$ & $16.56 f$ & $-1.07 a b c$ & $0.10 a b$ & 8.61ef & $13.69 b c$ \\
\hline FWW $(+\mathrm{N})$ & $16.54 f$ & $-0.69 a b$ & $0.24 a b$ & $9.23 d e$ & $14.20 a b$ \\
\hline LW & $16.58 f$ & $-0.94 a b c$ & $-0.07 a b$ & $10.52 b c$ & $14.44 a b$ \\
\hline LWW & $17.01 \mathrm{def}$ & $-0.89 a b$ & $-0.45 b$ & $9.85 c d$ & $14.14 a b$ \\
\hline $\mathrm{F}_{\mathrm{M}} \mathrm{WW}$ & $19.52 a b$ & $-1.42 b c$ & $-0.26 a b$ & $9.50 \mathrm{de}$ & $14.04 a b$ \\
\hline FWWHНH & $17.87 c d$ & $-0.69 a b$ & $0.14 a b$ & $12.88 a$ & $14.35 a b$ \\
\hline $\mathrm{W}_{\mathrm{C}}$ & $16.63 e f$ & $-0.50 a b$ & $0.29 a b$ & 8.61ef & $13.78 b c$ \\
\hline $\mathrm{W}_{\mathrm{C}}(+\mathrm{N})$ & $19.52 a b$ & $-1.04 a b c$ & $-0.98 b$ & $11.09 b$ & $14.97 a$ \\
\hline G & $19.94 a$ & $-2.25 c$ & $-0.80 b$ & $8.78 e f$ & $11.81 d$ \\
\hline
\end{tabular}

NOTE: $\mathrm{SOC}=$ soil organic carbon, $\mathrm{W}=$ wheat, $\mathrm{F}=$ fallow, $(+\mathrm{N})$ nitrogen added, $\mathrm{L}=$ lentil green manure, $\mathrm{F}_{\mathrm{M}}=$ fallow with added livestock manure (11.2 $\left.\mathrm{Mg} \mathrm{ha}^{-1}\right), \mathrm{H}=$ hay (grass and alfalfa), $\mathrm{W}_{\mathrm{C}}=$ wheat only if adequate spring soil moisture, otherwise the plot was fallowed, and $\mathrm{G}=\mathrm{a}$ mixture of native grass species. The SOC for 1995 was previously reported (Smith et al. 2015) and is provided in this table as a reference point.

NOTE: Means within a column not sharing a lowercase italic letter differ significantly at the $p<0.05$ level. 


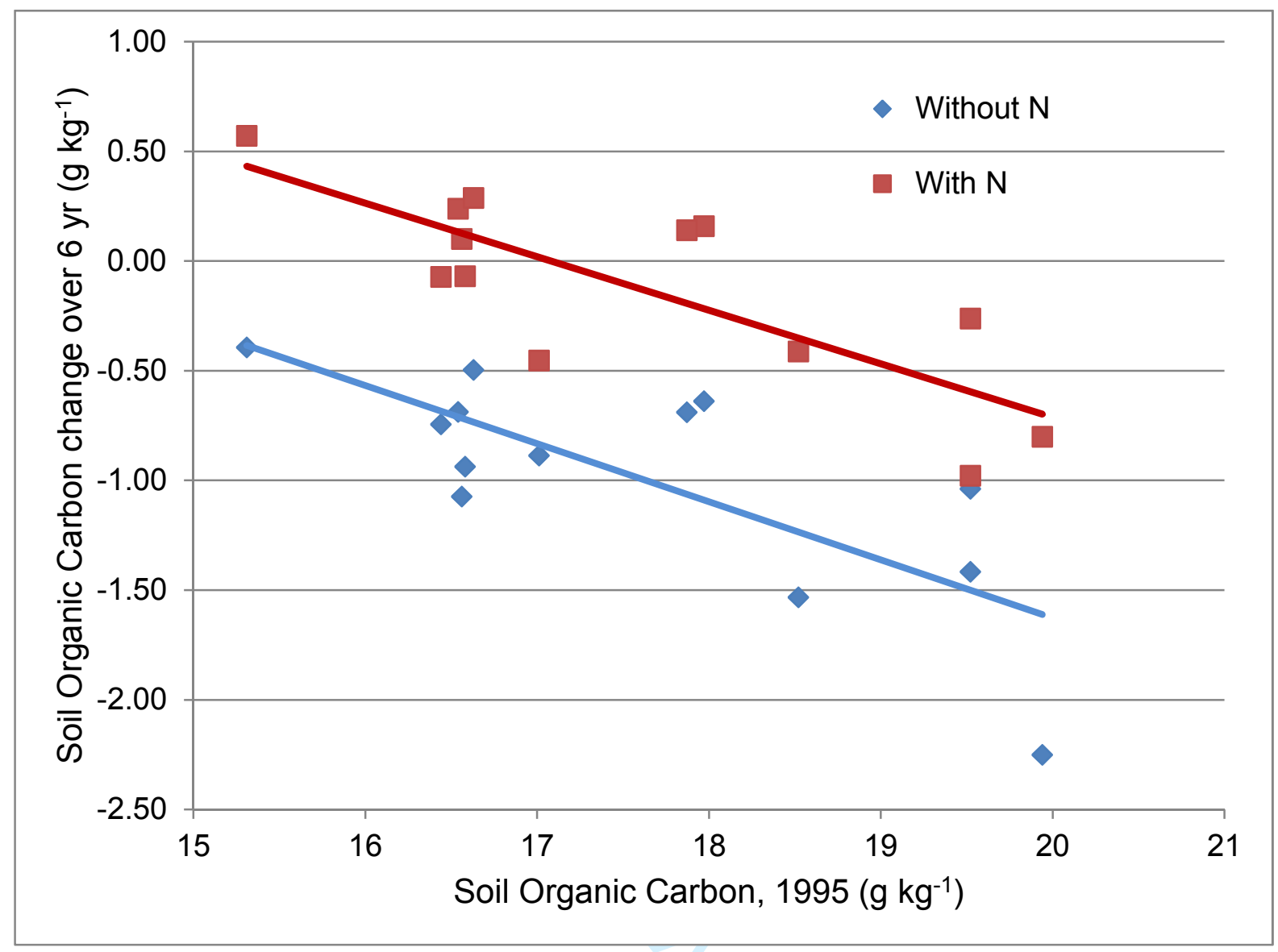

Figure 1. Change to soil organic carbon over 6 years given the initial soil organic carbon in 1995, without $\mathrm{N}$ added during the $6 \mathrm{yr}\left(\mathrm{R}^{2}=0.57\right)$ and with $\mathrm{N}$ added during the $6 \mathrm{yr}\left(\mathrm{R}^{2}=0.62\right)$. 